\title{
Article \\ The Role of the Social Sciences When Choosing University Studies: Motivations in Life Stories
}

\author{
Mario Corrales Serrano ${ }^{1, * \mathbb{D}}$, Jesús Sánchez-Martín ${ }^{2} \mathbb{D}$, José Moreno Losada ${ }^{1}$ and Francisco Zamora Polo ${ }^{3} \mathbb{D}$ \\ 1 Departamento de Didáctica de las Ciencias Sociales, las Lenguas, y las Literaturas, Facultad de Educación, \\ Universidad de Extremadura, 06006 Badajoz, Spain; jmorenol@unex.es \\ 2 Departamento de Didáctica de las Ciencias Experimentales y las Matemáticas, Facultad de Educación, \\ Universidad de Extremadura, 06006 Badajoz, Spain; jsanmar@unex.es \\ 3 Departamento de Ingeniería del Diseño, Escuela Politécnica Superior, Universidad de Sevilla, \\ 41011 Sevilla, Spain; fzpolo@us.es \\ * Correspondence: mariocorralesserrano@gmail.com; Tel.: +34-674-964-987
}

Citation: Corrales Serrano, M Sánchez-Martín, J.; Moreno Losada, J.; Zamora Polo, F. The Role of the Social Sciences When Choosing University Studies: Motivations in Life Stories. Educ. Sci. 2021, 11, 420. https:// doi.org/10.3390/educsci11080420

Academic Editors: Fred Dervin and Ismo T. Koponen

Received: 21 June 2021

Accepted: 6 August 2021

Published: 10 August 2021

Publisher's Note: MDPI stays neutral with regard to jurisdictional claims in published maps and institutional affiliations.

Copyright: (c) 2021 by the authors. Licensee MDPI, Basel, Switzerland. This article is an open access article distributed under the terms and conditions of the Creative Commons Attribution (CC BY) license (https:// creativecommons.org/licenses/by/ $4.0 /)$.

\begin{abstract}
The motivations that lead students to decide on a study modality or on a university degree provide relevant information to improve teaching-learning processes. This work addresses the question regarding the choice of study through analysis of four particular cases. They are special because the individuals chose their studies according to reasons different from the usual ones. To study these cases, interviews were carried out with the individuals. The results were subsequently analyzed according to a qualitative methodology using WebQDA software. The aim was to distinguish the incidence of internal and external motivations when choosing studies. The results obtained represent a contradiction with other pieces of research that analyzed the incidence of these types of motivations for choosing studies and allow for the assessment of various factors that may influence this process. The results obtained in this research indicate that the participants presented a high incidence of internal motivation. This allows for establishing some conclusions about the nature of those motivations when compared with the standard ones referred to in other works that dealt with a general population. The results reveal that in the subjects of this study's sample, there is a higher incidence of internal motivational factors, such as vocation, while in other subjects, external factors predominate, such as socioeconomic position.
\end{abstract}

Keywords: motivation; study modality; social sciences; humanities; qualitative research

\section{Introduction}

Research on the motivations that lead a student to decide to choose specific studies is an interesting challenge for the development of different areas of study, both in the high school and university stages [1,2]. From the perspective of the psychology of education, theories of motivation have been studied in depth [3,4]. These studies correlated the decision a person made in terms of studying one subject or another and the motivations that pushed him or her to do so $[5,6]$. The trends that are marked in each period and various evaluations of knowledge lead students to choose some study modalities or university degrees more frequently than others [7].

In this context, several authors [8-13] focus their attention on the importance of valuing humanities and social sciences due to the direct influence that these subjects have on the construction of western societies. Thus, the French philosopher Henry [8] warns of the dangers of undervaluing humanistic knowledge in society, qualifying the phenomenon of loss of importance of the humanities and the arts in today's society as barbarism. In the same way, authors such as Habermas [9] and Adorno [10] warn about the risk of granting all the epistemological force to scientific-technical knowledge, which leads society to live in technocratic systems rather than democratic ones. Furthermore, Ordine [11] highlights the usefulness of humanistic and social knowledge, which is usually considered useless in 
society. Similarly, Nussbaum [12,14] highlighted that the humanities and social sciences are losing relevance in the educational systems of many countries (e.g., the United States or India). This author presumed that this fact could be linked to the devaluation of human rights or democracy.

These arguments show the importance of knowing, analyzing and studying the motivational factors that lead students to decide on pursuing specific studies. As such, the analysis of trends regarding the choice of study (based on different factors, mainly quantitative) is not a novelty $[15,16]$. However, the study of specific situations through the case study methodology seems equally interesting, such as people who make decisions in a different way from the usual tendencies $[17,18]$. Knowing the motivations of these people can be useful for seeing the other side of the problem and offers significant information for the educational development of different knowledge areas. This methodology allows us to know the details and particularities of the decision-making process regarding study modality and, subsequently, a broader interpretation of the addressed problem.

The current work comprises a study of four particular cases that showed special characteristics with regard to the choice of study modality. The results obtained allow us to compare these factors with those highlighted by other research works [19-22]. In addition, no methods for encouraging the study of humanities and social sciences can be proposed if the advantages of selecting these subjects cannot be highlighted in opposition to the apparent general trend of studying sciences in high school.

\subsection{General Overview of Motivations in the Choice of Study}

Throughout their academic careers, there are many moments in which students have to make decisions and choose between different possibilities. Even during secondary education, students must decide on optional itineraries in their last year. Subsequently, they are pushed to select their subjects of study in high school [23]. When entering university, the first important decision is selecting what degree one wants to study. Within a university, there are again different moments in which optional subjects, curricular intensification itineraries or the study of new second- or third-stage degrees are chosen [24-26].

There are many very different reasons that lead a student to choose to study one subject or university degree or another. These reasons are mainly linked to the motivation with which this task is approached, and they partly determine the possibility of academic success for the student [27].

The concept of motivation is, therefore, very relevant in these kinds of studies. We begin by clarifying this concept and pointing out its most relevant aspects in terms of the choice of study.

Regarding motivation, we agree with the following statement from Pintrich et al. (2006):

"Motivation is the process that tries to explain how the set of thoughts, beliefs and emotions are transformed into a specific action to achieve a goal. It is the process by which the activity that is directed to an objective is instigated and maintained" [28].

This concept has a series of interesting peculiarities that can be analyzed in view of the main aim of the current work. The most relevant one is the difference between internal and external motivation, which many works have already addressed in the field of motivation psychology [29-32]:

- Internal motivation is the kind that has its origin in the person themself, such as vocation or preferences. Vocation is understood here as the inclination that a person feels to dedicate themself to a specific profession [33,34].

- External motivation is the type that has its origin in an external element that serves as a starting point for the person's action. This type of motivation is associated with the search for some type of reward associated with achievement of the objective, such as salary or social position $[35,36]$. 
Some studies also qualify this double aspect of motivation as intrinsic and extrinsic, although the concept refers to the same idea [37-39].

In the Spanish educational system, pre-university students must choose between three possible study modalities (sciences, social sciences and humanities or arts). Currently, there is an imbalance between the number of students in each modality. The most popular one is the sciences modality.

In previous works $[19,20]$, some authors studied the incidence of these two types of motivation in the process of choosing studies, especially focusing on the high school stage. There, external motivation predominated over internal motivation. The objective of these studies was to find out if the difference in the choice of the various study modalities in the pre-university students of the Spanish educational system was due to different types of influencing motivations in the students. There, the external motivation types predominated over the internal ones. Thus, factors such as employability [15], the grades obtained in previous stages and the expectations generated by them [40,41], the search for an adequate socioeconomic level [42] and the influence of family in academic matters [43,44] were reasons that led students to decide on specific study options in high school or certain degrees at the university level. Some other factors, such as the application of specific methodological strategies in the classroom $[45,46]$ or the influence of teachers [47,48], can also affect student motivation. These factors could probably be considered external emotional factors.

Going deeper, some studies tried to determine whether there were any differences between students undertaking various areas of study (humanities, social sciences or arts) in relationship with the motivations they expressed for choosing such studies $[7,20]$. Their conclusions did not show significant differences between the different types of motivations that were found in the choice of a modality, although they pointed out some interesting results. For example, they found that from the same motivation criteria, more than half of the high school students decided to study sciences, while 33\% chose the social sciences modality and only $11 \%$ decided to pursue humanities.

In these studies, a quantitative analysis is usually applied, determining the motivation criteria that influence the choice of each area of study. The main instrument for data collection is a questionnaire [20,49].

The current study considered the aforementioned studies in order to be able to contrast their results with those obtained here. However, our approach is not a quantitative one, but a qualitative study following the research method called Privileged Informants' Life Stories [50], which is presented in the following section. In this way, new and interesting information can be provided to know the types of motivation that affect the choices of study in pre-university students of the Spanish educational system.

\subsection{Choosing a Career According to Internal Motivations: A Case Study}

Few studies performed analyses from a qualitative point of view, and even fewer performed a study of people who presented special and different characteristics in this choice [51,52]. These types of distinctions are interesting for exploring the incidence of motivations, since the subjects may not follow the general trends described by previous quantitative studies [53,54]. Analysis of such differences could explain some aspects that are usually hidden in standard case studies.

As was previously mentioned [42,43], it can be observed that there is a relationship between the choices that students make and their motivations, which can be internal or external [55]. There seems to be a higher incidence of external rather than internal factors and a greater preference for the sciences area compared with the others. However, we pose the following questions: Is this behavior equal for all the students? Does it affect them in the same way? Are these factors the same for sciences and for humanities or social sciences students?

On these premises, we conducted a study of four interviews [56] in which the internal and external motivations of four individuals who opted for humanities or social studies 
were analyzed. They presented unique characteristics in relation to the subject under study, which is why they were considered privileged subjects [50].

The novelty and usefulness of this study lies in the fact that some individuals with very particular characteristics regarding their choices of studies have been selected and analyzed. The great contrast that the influence of internal motivations supposes in relation to the predominance of external motivations, which mainly affect the general population [21,57], provides a different view on this issue. Knowing the details of these very different processes is very relevant to be able to modify the general motivation processes.

Considering the results of the studies cited above in this regard, cases that act according to different variables would be interesting for this study because of the following aspects:

- In terms of interest in economic position, the interviewed individuals were not very affected by this variable, which was one of the most highly scored factors in the previous studies taken as a reference.

- Regarding social position or prestige, for this study, we selected subjects that showed little concern about this matter, in contrast to the studies reviewed.

- In terms of previous academic results, subjects whose academic marks did not seem to determine their choices of studies have been taken into account in the current work. In the reference studies, it was appreciated how the choice was partly determined by the average marks from previous stages of the studies.

- With regard to vocation, subjects who showed high levels of vocation in relation with their chosen area of study had been analyzed. This internal motivational factor was relevant in previous studies, although it was accompanied by other external ones.

In terms of employability, the individuals in the studied sample did not particularly consider this factor as a priority for choosing studies. This is significantly different to the relevance this aspect has shown in previous studies.

\subsection{Hypotheses and Objectives}

The main working hypotheses are the following:

- The reason the members of the sample chose their subjects in a different way is related to the fact that they have different motivations than the populations analyzed in previous studies.

- One of the elements that influences these differences is the fact that the individuals in the four cases decided to undertake university degrees in the areas of humanities and social sciences.

The main objective of this work was to analyze in detail the cases of people without similarities in their choices of studies, namely those who studied humanities and social sciences, to know the internal and external motivating factors that determined their choices. This analysis should give us some relevant data about these choices since the sample is not a standard one, and the individuals presumably chose their studies according to internal values and motivations rather than external ones.

This objective is, at the same time, complemented by other secondary objectives:

- To know which of the internal and external motivating factors lead some people to behave differently when choosing their studies;

- To determine if these people are more affected by the criteria of internal or external motivation in the selection of their studies;

- To analyze the possible link between the predominant motivation criteria and the humanistic and social studies on which the subjects of the sample decide.

\section{Material and Methods}

The parameters according to which this research was developed are presented below, involving a qualitative case study methodology with a sample of four privileged subjects. 
They were interviewed to obtain information about the choice for their studies and the relevant characteristics surrounding such choices.

\subsection{Sample}

Given the nature of the study, convenience sampling was performed based on the unique characteristics that were intended to be categorized. Bearing this in mind, the analysis of four unique cases of privileged subjects was carried out. They were selected because they presumably did not follow the usual pattern. The reasons for this divergence could be found in the fact that they made their choices under different life conditions or by non-standard lives and academic trajectories. Table 1 presents the characteristics of the subjects selected for this study.

Table 1. List of subjects considered privileged informants. Source: own elaboration.

\begin{tabular}{|c|c|c|c|}
\hline Students & Identification Data & Selected Studies & Characteristics \\
\hline Subject 1 & $\begin{array}{c}\text { Gender: Male } \\
\text { Age: } 24 \\
\text { Place of studies: Badajoz } \\
\text { Profession: Student }\end{array}$ & $\begin{array}{l}\text { Degree in Primary } \\
\text { Education }\end{array}$ & $\begin{array}{c}13.4 \text { in SUEE; began studying } \\
\text { engineering and then changed to } \\
\text { primary education }\end{array}$ \\
\hline Subject 2 & $\begin{array}{c}\text { Gender: Female } \\
\text { Age: } 21 \\
\text { Place of studies: Badajoz } \\
\text { Profession: Student }\end{array}$ & $\begin{array}{l}\text { Grade } \\
\text { in Early } \\
\text { Childhood } \\
\text { Education }\end{array}$ & $\begin{array}{l}\text { Decided to study education with } 11.40 \\
\text { in SUEE, against the opinion of family } \\
\text { and friends }\end{array}$ \\
\hline Subject 3 & $\begin{array}{c}\text { Gender: Male } \\
\text { Age: } 42 \\
\text { With a university degree } \\
\text { Place of studies: Cáceres } \\
\text { Profession: Teacher }\end{array}$ & $\begin{array}{l}\text { Spanish } \\
\text { Philology }\end{array}$ & $\begin{array}{l}\text { High score in SUEE and decided to } \\
\text { pursue a career without a cut-off grade }\end{array}$ \\
\hline Subject 4 & $\begin{array}{c}\text { Gender: Female } \\
\text { Age: } 39 \\
\text { Place of studies: Valencia } \\
\text { Profession: Teacher }\end{array}$ & $\begin{array}{l}\text { Geography } \\
\text { and History }\end{array}$ & $\begin{array}{l}\text { High score in SUEE and decided to } \\
\text { pursue a career without a cut-off grade }\end{array}$ \\
\hline
\end{tabular}

SUEE: Spanish University Entrance Examination.

- These four subjects had different characteristics than usual, which allowed us to conduct an analysis of factors that influenced their decisions in a different way from those that usually affect the student population. Some of those factors are presented above (see Section 1.2) and relate to the relationship between grades and the degree they chose to study, the utility or employability of such studies and some personal considerations about the academic discipline, which are clearly far from the usual visions of it.

These unique characteristics were what made these subjects relevant for the analysis of different elements that, in general, influenced the choice of study in a different way.

After analyzing the data present in papers that examined the motivations behind the choice of study modality, it can be affirmed that these subjects were special because they presented some characteristics (such as their qualifications, their family or academic environment and the influence of the general criteria of choice) that could have led them to choose studies related to science, and yet they made a very clear decision to study social sciences, as they affirmed in their interviews. Although there may be more subjects with these characteristics, the chosen ones were suitable for the purpose of this study, specifically because of their profile (i.e., they were students who would have been expected to choose science degrees, but in practice, their choices were different, as they opted for studies in the areas of humanities and social sciences). 


\subsection{Data Collection Procedure}

Given the objective of the study, it was necessary to determine in advance whether the subjects that were going to be part of the study sample properly fit the different pattern that we wanted to study. This objective implied, therefore, the application of a data collection procedure that ensured a good choice of subjects that would be part of the study. The steps followed during the process were as follows.

\subsection{Prospecting}

The first step was a survey of the selected subjects for confirming that they matched the necessary profile for the study. This survey was carried out through a pre-interview, in which the subjects were informally asked about the main factors to be analyzed:

- $\quad$ Selected studies;

- Main reasons why these studies were selected;

- Incidence of factors such as socioeconomic position, utility, employability or profession.

\subsection{Detailed Study of the Cases}

After this preliminary stage, which served to determine the selection of the four subjects for the study, an in-depth exploration of the internal and external motivations that determined their choices of study was carried out. The data collection instrument used as an element of contrast with the students of the sample was designed according to semistructured interview models $[58,59]$. It was a flexible data collection tool $[60,61]$ that may have allowed us to establish relationships with the rest of the information collected using other means. Table 2 summarizes the script from which the interviews were developed.

Table 2. List of subjects considered privileged informants. Source: own elaboration.

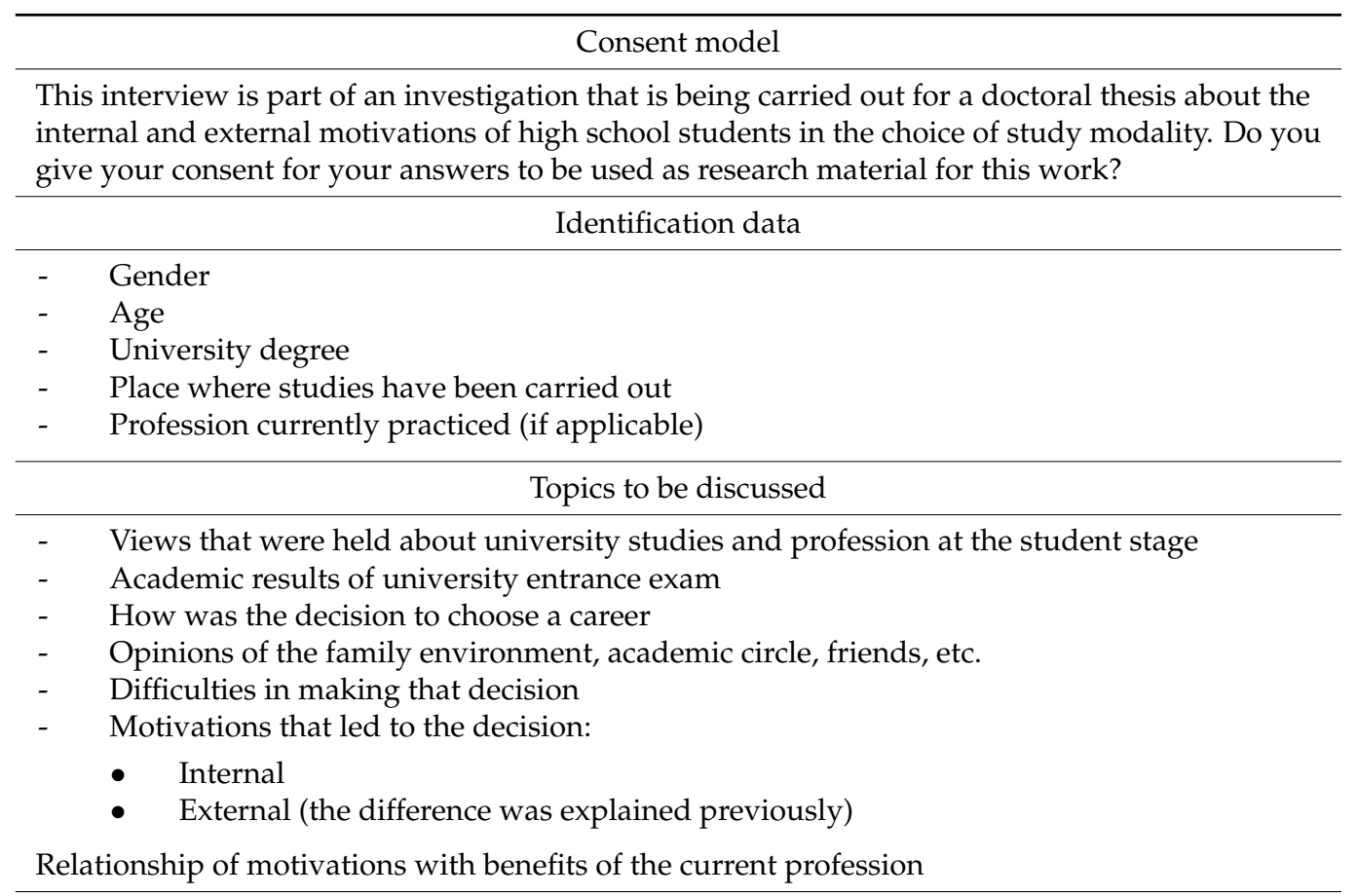

$$
\text { Additional information }
$$

The subject can express himself or herself freely, regardless of the issues that appear explicitly in the script

The design of this semi-structured interview was reviewed and validated by experts linked to research before its application. In this validation process, the experts checked 
whether the structure of the interview conformed to the objectives pursued and to the parameters of this type of interview.

\subsection{Transcription and Confirmation of Information}

After the interviews were carried out in person, and in order to be able to analyze the data accurately, the following procedures were carried out:

- The interviews were fully transcribed by the researchers so that we could work on a written text.

- These transcripts were reviewed by the interviewees to ensure their conformity with the information transmitted and transcribed and for avoiding possible mistakes or errors of interpretation by the researchers themselves.

- These two procedures concluded the data collection task, and the data were thus adequately prepared for analysis and categorization. Figure 1 summarizes the data collection procedure.

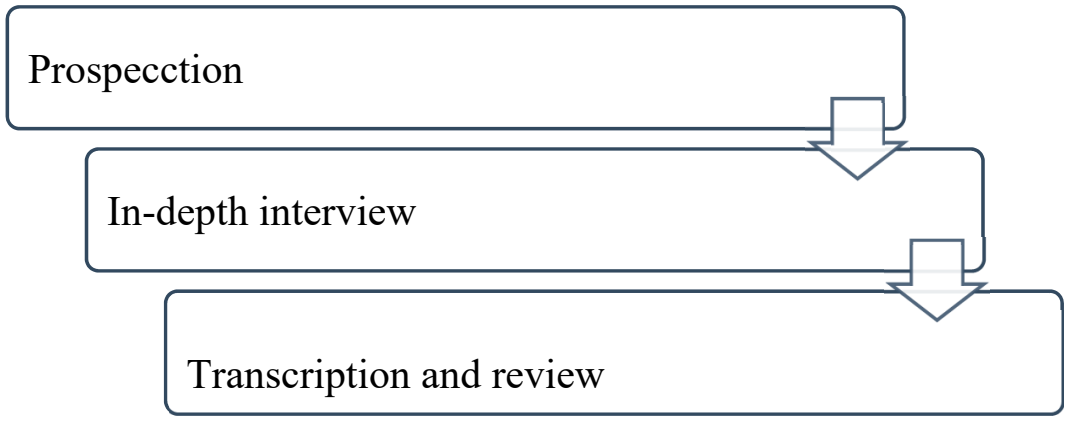

Figure 1. Data collection procedure. Source: own elaboration.

\section{Analysis Process}

The methodology of the particular cases was used in the current study $[17,62,63]$. It allowed us to delve into the characteristics of some subjects who were selected because, as was previously mentioned, they generally presented special conditions for study in terms of motivations. Consequently, they could be considered privileged subjects $[50,56]$. Thus, the results obtained in this analysis allow for a comparative study [64] to be carried out with other studies that analyzed these motivations in a general way. This methodology was considered to be the most fitting to fulfill the objectives of the study, as it allowed going deeper and beyond the numerical data.

\section{Data Analysis}

Analysis of the four interviews was carried out using a qualitative methodology with the WebQDA qualitative analysis software [65] in order to categorize the internal and external motivating factors that led these four subjects to decide on their studies and professions with the same categories used in previous studies [20,66-68]. Consequently, our results will be comparable with the data from those studies.

The software used allowed for associating the ideas that appeared in texts to a system of nodes that could be worked with in WebQDA [65], thus making it possible to draw global conclusions from textual data. Figure 2 describes the process by which the data were analyzed in this software. 


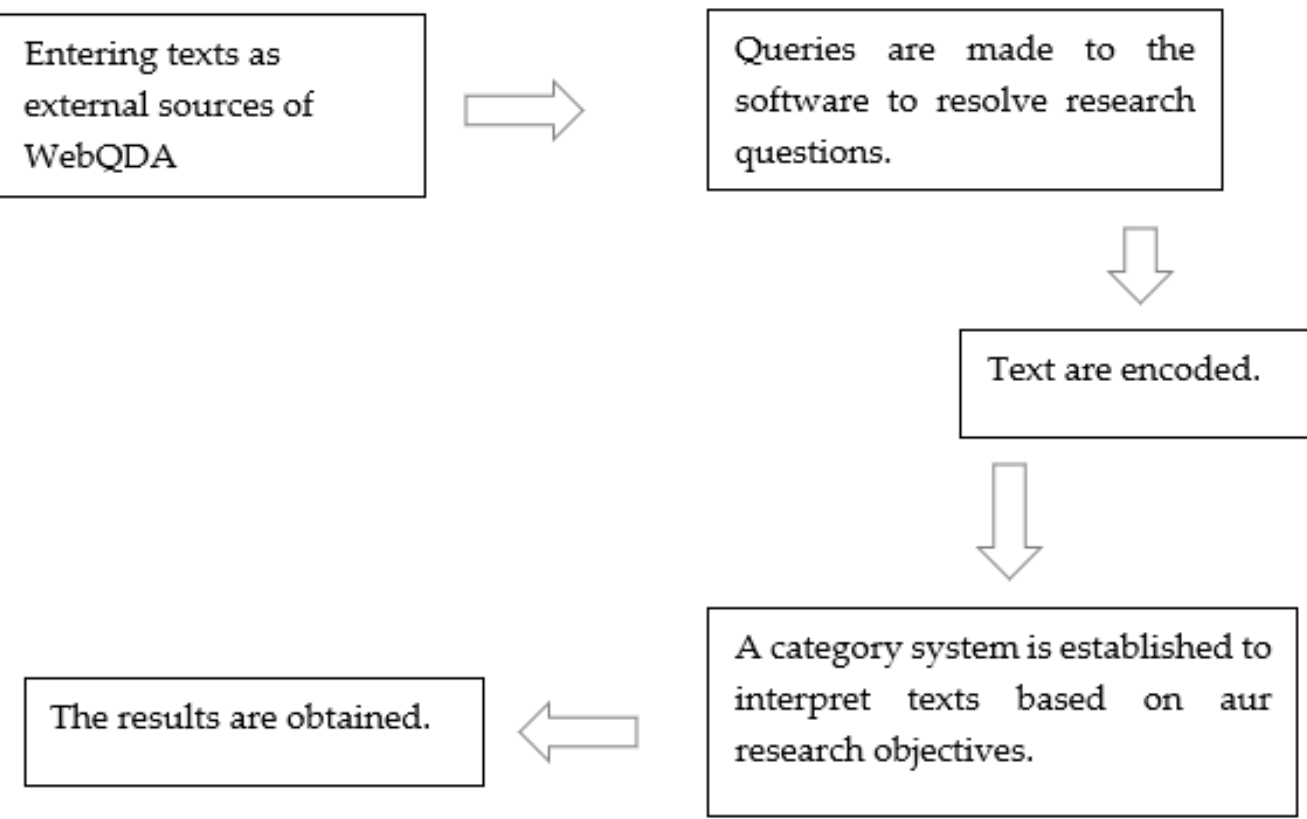

Figure 2. Work procedure with qualitative WebQDA software. Source: Corrales, 2020 [19].

The analysis process was carried out as follows:

1. The first step was subject selection, using the procedure indicated above, and conducting the interview based on the described parameters.

2. The next step was categorization of the contents of the interviews through a work project enhanced with the qualitative WebQDA software, which allowed conclusions to be drawn about the interview contents.

3. This categorization of the information in the texts according to the research objectives was carried out by linking paragraphs of the interviews with key concepts of internal or external motivation, which were subsequently diversified into several variables taken from previous works $[69,70]$. Since previous studies were conducted for identifying the most influential internal and external criteria, these items in the questionnaire were selected for evaluation during the interview (e.g., salary, social position or vocation). In this way, the analysis of the structured interviews aimed to identify parts of the texts that could be linked to the criteria of internal and external motivation that most influenced students, judging by the data of these reference studies. The system of branched nodes that was used can be seen in Figure 3. Based on this network of nodes, we categorized parts of the texts, associating them with one of the general types of motivation and some of the subtypes.

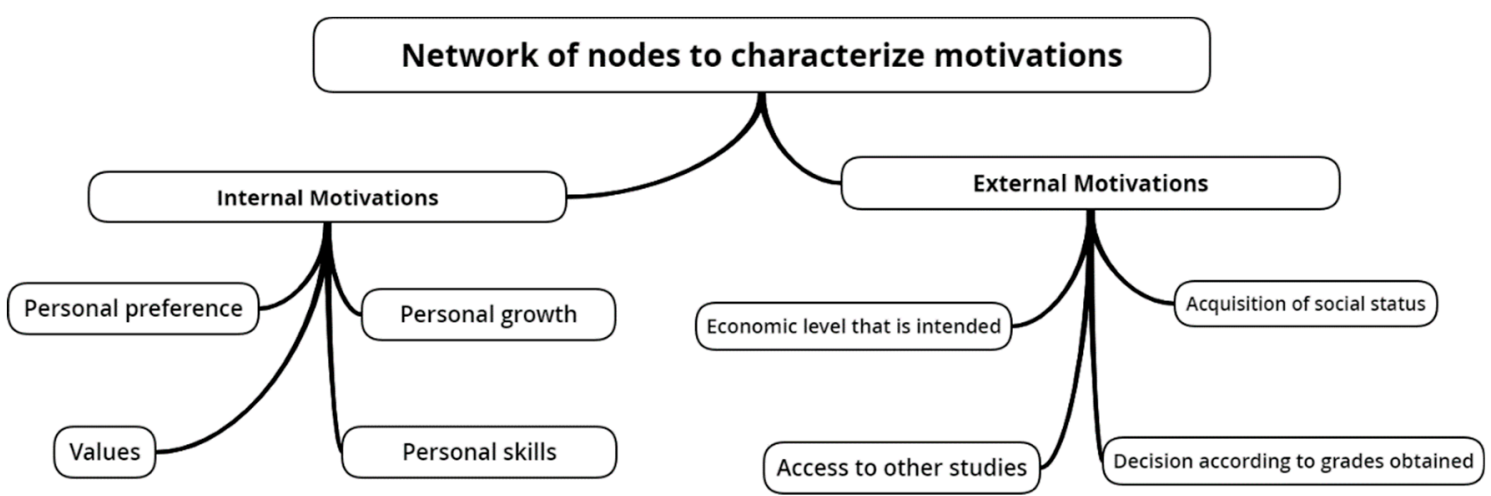

Figure 3. Network of branched nodes to categorize the motivations of the students. Source: Corrales et al., 2020 [20]. 
4. In order to give consistency and strength to the categorization, the classifications of nodes and the associations of concepts were contrasted by two separate experts. In case of divergence, a third expert intervened to define the association.

Some examples of categorization of parts of the responses of the sample subjects are presented, noting the type and subtype of motivation from the node scheme used.

Example 1: Criterion of personal preference (internal motivation)

Individual 3:

"At the beginning, what made me decide on literature, I think it was the fact that I liked it, and also the closeness to figures that had marked my way of understanding literature, as well as some teachers and also the possibility of investigating in writing, in order to know interpretations and to contribute new visions about what I was studying.

I think the difficulty that arose was thinking about what I would work on. It is true that I have always liked teaching, but the study of literature was not going to offer me too many possibilities, it is also very difficult to live from academic disciplines like this if it is not from teaching".

Example 2: Criterion of social status (external motivation)

Individual 4:

"Currently I am working as a teacher, and I am comfortable with it because it offers me a more or less secure job and an adequate socioeconomic status. It is true that my profession is not the prestigious one or the highest paid profession in the world, but, above all, I feel comfortable because I am doing what I like and because my belief is that what I teach gives my students an interesting view of things and some keys to interpret the world in which we live".

Example 3: Criterion of personal preference (internal motivation) and criterion of economic level that is intended (external motivation)

Individual 3:

"My marks in SUEE were good, I got an 8.75 (out of 10) and that gave me the possibility of accessing any career in arts and even some in sciences. Both my family and my colleagues wanted me to study a degree in which it would be easy for me to find jobs and that would provide me with good social status and good living conditions".

Individual 4:

"In SUEE I had good results, an average of 8, with which I had many possibilities of agreeing to study whatever I wanted. Right away, both my family and my friends and even myself at some point, thought about the best way to take advantage of that good result, which was what could help me to have more safety in the future in a job with a good salary, with stability".

Once the categorization process had been carried out, the software could obtain information to respond to the research objectives. Questions about the following subjects had to be answered:

- Internal and external motivating factors that influence students' choices of study;

- Predominance of internal or external criteria in the students;

- Possibility of linking the incidence of these criteria with the fact that the students decide on studying humanities and social sciences. 


\section{Results}

The analysis of the results obtained, according to the categorization into nodes of meaning, gave rise to interesting associations, which are presented below.

Regarding the presence of expressions or concepts in these interviews that could be associated with internal or external motivation criteria, Figure 4 shows that the internal type criteria were mentioned more frequently than the external ones. This result is consistent with the criteria according to which the four participating subjects were selected and is contradictory to other studies' results [20,25,42], in which external criteria were more important than internal ones in determining study options.

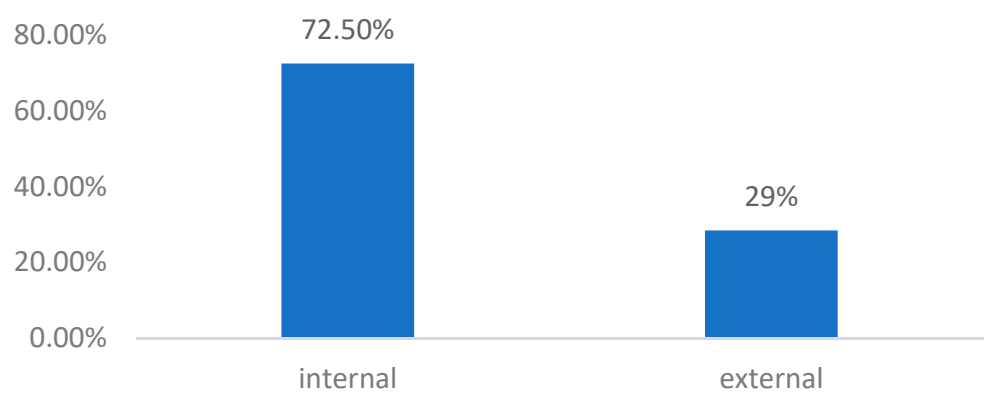

Figure 4. Frequency of choice of internal and external motivation criteria in the interviews with the subjects of the sample.

The fact that internal motivation criteria were more frequently mentioned verifies what was pointed out in the first of the working hypotheses and allows for establishing, at least for these cases, a relationship between a different type of study choice and the incidence of different motivations.

Compared with other studies $[19,20]$, it can be observed that in the subjects analyzed in this case study, the preponderance of internal motivation criteria was much more important than in a general sample, as can be seen in Table 3 .

Table 3. Comparison of incidence of internal and external motivation criteria between the results of this study and those of [19]. Source: own elaboration.

\begin{tabular}{cccc}
\hline & Quantitative Analysis & Qualitative Analysis & $\begin{array}{c}\text { Study of Cases } \\
\text { (Current Work) }\end{array}$ \\
\hline Int. Criteria & 69 & $52 \%$ & $72 \%$ \\
Ext. Criteria & 74 & $48 \%$ & $29 \%$ \\
\hline
\end{tabular}

In the study on a sample of 240 high school students [19], on a Likert scale of 1-10, the average of the scores obtained for the internal criteria in the application of the T-student test was 69 , while the external criteria obtained a score of 74 . In the qualitative part of this same study [32], the authors carried out an analysis using similar criteria to those employed in the current work. The frequency of appearance of internal and external criteria was $52 \%$ and $48 \%$, respectively. In comparison with our own data (72\% internal motivation criteria and $29 \%$ external motivation criteria), the difference in the incidence of internal and external criteria is clear and striking.

The specific frequency of the motivation criteria selected for the qualitative analysis is shown in Figures 5 and 6 . As can be observed, internal criteria were much more frequent than external ones. Among the internal criteria, the frequency of appearance of references to personal preferences and values stood out, while in the external ones, the most frequent one was that of social status. 


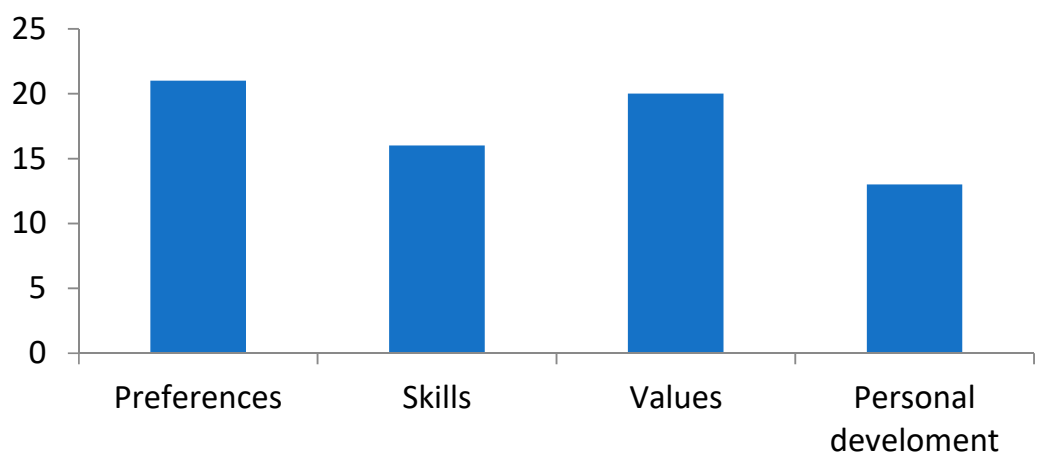

Figure 5. Frequency of use of internal motivation criteria in interviews with privileged subjects.

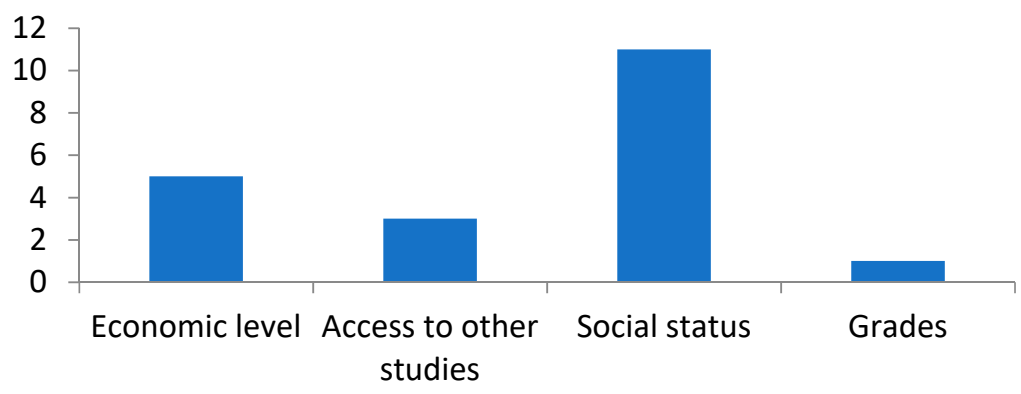

Figure 6. Frequency of use of external motivation criteria in interviews with privileged subjects.

In previous studies $[16,20]$, relevance was also given to criteria such as personal preferences or skills.

Comparing the results of Figure 6 with the incidence of factors such as the economic level in previous studies $[16,20,25,42]$, it can be concluded that the participants in this case study clearly differed from the participants in other studies in terms of the priority they gave to this criterion. This appears frequently in other studies but has a low appearance in the current one. However, there is similarity between the previous studies and this case study in terms of the importance given to the criterion of social status.

Based on the results, and in reference to the research objectives, it can be stated that the subjects of this study showed a higher incidence of internal motivation criteria (especially personal preferences, skills and personal development) than external motivation criteria (only the assessment of social status can be highlighted), and these data support their selection for the study.

Based on this, a verification interpretation of the second working hypothesis may be feasible. The idea here was that the cause of the detectable differences in these cases was the fact that all the subjects decided on pursuing humanities and social studies. In addition, we analyzed the motivations of the individuals in relation to the area of social sciences. In both cases, the possibility arises that the cause of these differences is the fact that the participants all decided on pursuing humanities and social studies, which are not the most common subjects in the total population. This was not demonstrated in the applied tests, but it can be affirmed that in these four cases, there was a correlation between the higher incidence of internal criteria over external ones and the fact that the subjects of the sample were studying or studied humanities and social sciences.

\section{Discussion}

The results obtained in the study of these four cases offer interesting contrasts with the reviewed scientific literature regarding the motivations that lead students to decide on some specific studies compared with others. Here, we present some of the most relevant contrast elements in this regard. 


\subsection{Assessment of Differences between Internal and External Criteria}

Regarding the difference in the frequency of assessment of internal and external motivation criteria, the results of this study showed a prevalence of internal motivation criteria over external motivation criteria in contrast to other studies, in which there was either a higher incidence of external motivation criteria or there was not such a wide difference between one and the other.

Starting with the study by Corrales [19], which we used as a reference to categorize the texts of the interviews, a considerable difference in the percentages of internal and external motivation criteria frequency must be noted. In the analysis of these four interviews, a $72.5 \%$ incidence of internal motivation was seen, while in the referenced study, there was only a $52 \%$ incidence of this type of motivation.

On the other hand, a study that addressed these same issues from a quantitative point of view $[7,19]$ showed different results.

It is also interesting to assess the results of this study by contrasting them with other studies that address the question of motivation but do not make a specific distinction between internal and external motivation.

The study by Lagares [21], carried out with almost 200 students in their first or second year of high school, concluded that the most important motivator in the choice of studies in the analyzed sample was that of vocation (which, in our study, was identified as a criterion of internal motivation). It also refers to career opportunities (which was an external criterion for us).

Additionally, the study carried out by Sánchez-García [71] in relation to the choice of university degree revealed some interesting results. When analyzing the incidence of personal, professional or social-family factors on a scale from one to five, it was concluded that personal motivations (comparable with the internal motivation criteria of our study) had an effect value of 2.9 for humanities studies, 3.8 for social-legal studies, 3.3 for studies in the experimental and health fields and 4.1 in technical studies. On the other hand, the professional criteria (comparable to the external motivation criteria of our study) had an effect value of 4.1 for humanities studies, 3.8 for social-legal studies, 3.9 in experimental and health studies and 3.8 in technicians. It is thus clear that the studied cases in the current work significantly differed from this pattern.

According to these results, it could be said that, unlike the data shown in our work, in the humanities modality, professional reasons seem to have more influence, while in the rest, the predominant factors are personal ones. It is necessary to realize that, although it is not the same division presented in our empirical study, personal motives can be classified as internal while professional motives are classified as external ones, taking into account the theoretical development from which the criteria have been classified [72,73].

In another study on the choice of youth studies and high schools in Mexico carried out by Weis [74], the authors reported the incidence of different types of motivations in the choice of university studies, among which the criterion of professional opportunities stood out, in line with the data presented in the study by Álvarez [23].

\subsection{Assessment of Specific Criteria}

Regarding the frequency of mention of the different motivation criteria, the results obtained in this study contrast with some studies where the importance of factors such as the average grades were highlighted. That is the case for the work by Martínez [75,76]. This author carried out a study involving 6164 students in Granada, Spain. The results showed a relationship between high average marks and the pursual of bio-sanitary and social and legal science degrees and a relationship between low marks and the selection of some engineering modalities.

On the other hand, we found links between the factor of cut-off grades and vocation in high school and specific professional training of students, linking a range of higher average grades with university pursuits in the branch of sciences and lower average grades with degrees in humanities and social sciences [77]. An assessment of job opportunities [78] still 
showed a greater trend of choosing degrees with better job opportunities in students who obtained better average grades in high school.

In addition, the socioeconomic variable was relevant and was reflected in certain studies $[79,80]$, which highlighted this factor as one of the most influential, unlike in the present study of the four interviews, which showed a lower incidence of this value.

\section{Conclusions}

Having analyzed the interviews based on the research design described above and contrasting the information collected with other studies, the main conclusions obtained are the following:

- All the participants obtained high average grades, interpreted as providing the possibility of accessing any university degree.

- The dissociation that was established between the decision to choose studies in correlation with the obtained average grades was interesting because it appeared to be in contrast with cases referenced in other studies.

- In all cases (particularly in some with more relevance), the influence of the family and friend environment manifested in the decision about university studies, although the criterion of the individual prevailed over that of the environment, even when it manifested itself against them.

- The strength of internal motivation was related to the internal well-being of the profession the individual carried out or wanted to join, in contrast to the importance of external factors in our empirical study.

- The results showed the capacity of the interviewees to "swim upstream" and to manage the misunderstandings of those around them, who analyzed the decision to undertake studies with external criteria, while the individual did so with internal criteria.

- Though it could be expected that interviewed individuals would worry about their future, job possibilities, social position, etc., when thinking about their future, these subjects did not focus so much on extrinsic factors, such as socioeconomic situation or employability, but rather on feeling happiness at doing what they felt called to do (i.e., their vocations). Concern for the future appeared in these interviews as concern for the pursuit of happiness.

- Lastly, the fact that the interviewed subjects manifested an explicit awareness of the relationship that existed between the studies they decided to pursue and their ability to contribute to the society in which they live was highlighted.

According to the previous data analysis and discussion, we consider the general objective of this study to be fulfilled (i.e., to analyze cases of singular subjects who study humanities and social sciences in terms of their choices of study in depth and to know the internal and external motivating factors that determined their choices). The analysis showed that the motivating factors that the interviewees referred to were mostly internal ones, in contrast to what is seen in general studies on the same topic. In the study, all the participants came from the areas of humanities and social sciences, which allowed us to consider a correlation between this type of motivation and the degrees chosen.

Among the limitations of this study, one could refer to the methodology for studying life stories and privileged informants, which are applied for the analysis. Although it allows for in-depth analysis, data extrapolation cannot be performed in quantitative terms, but rather by qualitatively comparing the incidence of motivations. Despite the methodology suggesting this, the sample is limited if the intention is to present quantitative and universal results. This could be a research topic for further studies.

The individuals analyzed belong to the geographical area of Spain, so it would be convenient to study individuals from other places with other academic contexts to detect possible variations.

Regarding recommendations for policymakers, there is still a long way to go to recognize the value of the humanities and social sciences in a highly technocratic world. Sometimes, these disciplines are valued as second-rate. In this sense, authorities should 
publicly recognize the need for the humanities and social sciences in the problems facing the world. Some of the most important challenges we face require the participation of professionals from these disciplines. For example, the development of artificial intelligence requires the participation of philosophers who ensure that technology is at the service of human development, and the reduction in inequality and poverty must include disciplines such as economics and sociology. Therefore, concrete actions should be taken along the educational pathways of students so that they can appreciate the importance of these disciplines.

Author Contributions: Conceptualization, M.C.S., J.S.-M. and J.M.L.; methodology, M.C.S., F.Z.P. and J.S.-M.; software, M.C.S. and J.S.-M.; validation, F.Z.P., J.S.-M. and M.C.S.; formal analysis, M.C.S. and J.S.-M.; investigation, M.C.S., J.S.-M.; J.M.L. and F.Z.P.; resources, M.C.S., J.S.-M. and F.Z.P.; data curation, M.C.S.; writing-M.C.S.; writing—review and editing, F.Z.P. and J.S.-M.; visualization, F.Z.P. and J.S.-M.; supervision, J.S.-M., F.Z.P., J.M.L.; project administration, J.S.-M.; funding acquisition, J.S.-M. All authors have read and agreed to the published version of the manuscript.

Funding: This work was funded by the research project EDU2016-77007-R (AEI/ERDF, EU) and the research projects GR18004 and IB18004 (Junta de Extremadura and the European Regional Development Fund).

Institutional Review Board Statement: Not applicable.

Informed Consent Statement: Informed consent was obtained from all subjects involved in the study.

Data Availability Statement: Not applicable.

Acknowledgments: The authors thank the four subjects that participated in this study. It would not have been possible without their collaboration.

Conflicts of Interest: The authors declare no conflict of interest.

\section{References}

1. Farmer, A.W. The Impact of Student-Teacher Relationships, Content Knowledge, and Teaching Ability on Students with Diverse Motivation Levels. Lang. Teach. Educ. Res. 2018, 1, 13-24. Available online: https://dergipark.org.tr/en/download/article-file/ 481322 (accessed on 13 May 2021).

2. Wigfield, A.; Wentzel, K.R. Introduction to motivation at school: Interventions that work. Educ. Psychol. 2007, 42, 191-196. [CrossRef]

3. Gilbert, I. Motivar Para Aprender en el Aula: Las Siete Claves de la Motivación Escolar; Paidós: Barcelona, Spain, 2005.

4. Mateos, M.; Palmero, F.; Fernández-Abascal, E.; Martínez, F.; Choliz, M. Teorías Motivacionales Psicología de la de la Motivación y la Emoción; Mc Graw Hill: Madrid, Spain, 2002; pp. 155-186.

5. Nayir, F. The Relationship between Student Motivation and Class Engagement Levels. Eurasian J. Educ. Res. 2017, 17, 59-78. Available online: https:/ / files.eric.ed.gov/fulltext/EJ1158398.pdf (accessed on 17 May 2021). [CrossRef]

6. Klaeijsen, A.; Vermeulen, M.; Martens, R. Teachers' innovative behaviour: The importance of basic psychological need satisfaction, intrinsic motivation, and occupational self-efficacy. Scand. J. Educ. Res. 2018, 62, 769-782. [CrossRef]

7. Corrales, M.; Sánchez, J.; Moreno, J.; Zamora, F. Las motivaciones de los jóvenes para el estudio: Raíces y consecuencias. Cuad. Investig. Juv. 2018, 4, 60-79. [CrossRef]

8. Henry, M. La Barbarie; Puf-Quadrige: Paris, France, 2001.

9. Habermas, J. Wissenschaft und Technik als Ideologie. Technik und Wissenschaft als Ideologie; Suhrkamp: Berlin, Germany, 1969.

10. Adorno, T.W. Gesammelte Schriften in 20 Bänden: Band 4: Minima Moralia. Reflexionen aus dem beschädigten Leben; Suhrkamp: Berlin, Germany, 1991.

11. Ordine, N. L'utilità Dell'inutile; Bompiani: Milano, Italy, 2013.

12. Nussbaum, M.C. Not for Profit: Why Democracy Needs the Humanities; Princeton University Press: New York, NY, USA, 2010.

13. Nussbaum, M.C. Cultivating Humanity; Harvard University Press: Cambridge, UK, 2005.

14. Nussbaum, M.C. La Fragilidad del Bien: Fortuna y Ética en la Tragedia y la Filosofía Griega; Antonio Machado Libros: Madrid, Spain, 2017.

15. Estrada, P. Factores que intervienen en la elección de carrera de estudiantes de bachillerato de dos modalidades educativas. In Proceedings of the XI Congreso Nacional de Investigación Educativa, Ciudad de, México, México, 7-11 November 2011. Available online: http:/ / www.comie.org.mx/congreso/memoriaelectronica/v11/docs/area_16/2028.pdf (accessed on 22 May 2021).

16. Usuga, A.M.; Mesa, S.R. La influencia de factores psicológicos como autoestima, autoconcepto y autoeficacia en el rendimiento académico en adolescentes. Rev. Electrónica Psyconex 2016, 8, 1-11. 
17. Monge, E.C. El estudio de casos como metodología de investigación y su importancia en la dirección y administración de empresas. Rev. Nac. Adm. 2010, 1, 31-54.

18. Rafiola, R.; Setyosari, P.; Radjah, C.; Ramli, M. The Effect of Learning Motivation, Self-Efficacy, and Blended Learning on Students' Achievement in The Industrial Revolution 4.0. Int. J. Emerg. Technol. Learn. 2020, 15, 71-82. Available online: https://www.learntechlib.org/p/217073/ (accessed on 14 May 2019). [CrossRef]

19. Corrales Serrano, M. Estudio de las Motivaciones internas y externas para la elección de modalidad del alumnado de Bachillerato. Incidencia en la Didáctica de las Ciencias Sociales. Ph.D. Thesis, Universidad de Extremadura, Badajoz, Spain, 2020.

20. Corrales-Serano, M.; Modeno-Losada, J.; Sánchez-Martín, J.; Zamora-Polo, F. Estudio cualitativo de las motivaciones del alumnado de Bachillerato en referencia a la modalidad de estudios. Campo Abierto. Rev. Educ. 2020, 39, 85-99. [CrossRef]

21. Lagares, E.C.; Ordaz, F.G.; Lagares, A.R. Evidencias empíricas en el proceso de elección de los estudios universitarios. Enseñanza y Teach. Rev. Interuniv. Didáctica 2012, 30, 45-62.

22. Sánchez García, M. La orientación universitaria y las circunstancias de elección de los estudios. Asoc. Interuniv. Investig. Pedagógica Miemb. Eur. Educ. Res. Assoc. 2001, 19, 39-61.

23. González, M.Á.; Gazo, P.F.; Fonseca, M.T. La problemática de la transición bachillerato-universidad en la Universidad de Barcelona. Rev. Española Orientación Psicopedag. 2011, 22, 15-27. [CrossRef]

24. Avendaño Bravo, C.; González Urrutia, R. Motivos para ingresar a las carreras de Pedagogía de los estudiantes de primer año de la Universidad de Concepción. Estud. Pedagógicos 2012, 38, 21-33. [CrossRef]

25. Feixas i Condom, M. La influencia de factores personales, institucionales y contextuales en la trayectoria y el desarrollo docente de los profesores universitarios. Educar 2004, 33, 31-59. [CrossRef]

26. Soler Julve, I. Los Estudiantes Universitarios: Perfiles y Modalidades de Vinculación con el Estudio en la Universidad Española. Ph.D. Thesis, Universidad de Valencia, Valencia, Spain, 2013.

27. Marina, J.A. Talento, Motivación e Inteligencia: Las Claves Para una Educación Eficaz; Grupo Planeta: Barcelona, Spain, 2013.

28. Pintrich, P.R.; Schunk, D.H.; Luque, M.L. Motivación en Contextos Educativos: Teoría, Investigación y Aplicaciones; Pearson Prentice Hall: Madrid, Spain, 2006.

29. Cordova, D.I.; Lepper, M.R. Intrinsic motivation and the process of learning: Beneficial effects of contextualization, personalization, and choice. J. Educ. Psychol. 1996, 88, 715. [CrossRef]

30. Baquero, R.; Limón, M. Teorías del Aprendizaje; Universidad Nacional de Quilmes: Buenos Aires, Argentina, 1999.

31. Domínguez-Alonso, J.; Domínguez-Rodríguez, V.; López-Pérez, E.; Rodríguez-Gonzáles, M. Motivación e inteligencia emocional en estudiantes de Educación Secundaria Obligatoria. Rev. Estud. Investig. Psicol. Educ. 2016, 3, 94-101. [CrossRef]

32. Tapia, J.A. Motivación para el aprendizaje: La perspectiva de los alumnos. La Orientación Esc. Centros Educ. 2005, 209-242.

33. Bailey, D.; Almusharraf, N.; Hatcher, R. Finding satisfaction: Intrinsic motivation for synchronous and asynchronous communication in the online language learning context. Educ. Inf. Technol. 2021, 26, 2563-2583. [CrossRef] [PubMed]

34. Liu, Y.; Hau, K.; Liu, H.; Wu, J.; Wang, X.; Zheng, X. Multiplicative effect of intrinsic and extrinsic motivation on academic performance: A longitudinal study of Chinese students. J. Pers. 2020, 88, 584-595. [CrossRef] [PubMed]

35. Cattell, R.B.; Kline, P. El análisis Científico de la Personalidad y la Motivación; Pirámide: Madrid, Spain, 1982.

36. Mayor, L.; Tortosa, F. Perspectivas históricas acerca de la psicología de la motivación. Rev. Electrónica Motiv. Emoción 2005, 8, 20-21. Available online: http:/ / reme.uji.es (accessed on 18 May 2021).

37. Serin, $\mathrm{H}$. The use of extrinsic and intrinsic motivations to enhance student achievement in educational settings. Int. J. Soc. Sci. Educ. Stud. 2018, 5, 191-194. [CrossRef]

38. Froiland, J.M.; Oros, E. Intrinsic motivation, perceived competence and classroom engagement as longitudinal predictors of adolescent reading achievement. Educ. Psychol. 2014, 34, 119-132. [CrossRef]

39. Boström, L.; Bostedt, G. What about Study Motivation? Students' and Teachers' Perspectives on What Affects Study Motivation. Int. J. Learn. Teach. Educ. Res. 2020, 19, 40-59. [CrossRef]

40. Baños, R.; Ortiz-Camacho, M.d.M.; Baena-Extremera, A.; Tristán-Rodríguez, J.L. Satisfacción, Motivación y Rendimiento Académico en Estudiantes de Secundaria y Bachillerato: Antecedentes, Diseño, Metodología y Propuesta de Análisis Para un Trabajo de Investigación. Espiral. Cuad. Prof. 2017, 10, 40-50. Available online: http:/ / espiral.cepcuevasolula.es/ (accessed on 9 May 2021). [CrossRef]

41. Picó Lozano, M. La Importancia de la Motivación en el Rendimiento Académico de los Estudiantes de Educación Secundaria Obligatoria; Trabajo fin de Grado, Universidad de Illas Baleares: Mallorca, Spain, 2018. Available online: http://hdl.handle.net/11201/3589 (accessed on 9 May 2021).

42. Bravo-Torres, G.; Vergara-Tamayo, M.A. Factores que determinan la elección de carrera profesional: En estudiantes de undécimo grado de colegios públicos y privados de Barrancabermeja. Psicoespacios 2018, 12, 35-48. [CrossRef]

43. Cortés Pascual, P.A.; Conchado Peiró, A. Los Contextos Parentales y Académicos y los Valores Laborales en la Toma de Decisiones en Bachillerato. Estud. Sobre Educ. 2012, 22, 93-114. Available online: http://hdl.handle.net/10251/34308 (accessed on 13 May 2021).

44. Bernal, A.C.A.L.; Arocena, F.A.L.; Navarro, L.I.C. Toma de decisiones, estilos de comunicación en el conflicto y comunicación familiar en adolescentes bachilleres. Enseñanza Investig. Psicol. 2012, 17, $295-311$.

45. Gómez-Carrasco, C.-J.; Monteagudo-Fernández, J.; Moreno-Vera, J.-R.; Sainz-Gómez, M. Effects of a gamification and flippedclassroom program for teachers in training on motivation and learning perception. Educ. Sci. 2019, 9, 299. [CrossRef] 
46. Zamora-Polo, F.; Corrales-Serrano, M.; Sánchez-Martín, J.; Espejo-Antúnez, L. Nonscientific University Students Training in General Science Using an Active-Learning Merged Pedagogy: Gamification in a Flipped Classroom. Educ. Sci. 2019, 9, 297. [CrossRef]

47. Khalilzadeh, S.; Khodi, A. Teachers' Personality Traits and Students' Motivation: A Structural Equation Modeling Analysis. Curr. Psychol. 2021, 40, 1635-1650. Available online: https://link.springer.com/article/10.1007/s12144-018-0064-8 (accessed on 5 May 2021). [CrossRef]

48. Zhou, M.; Teo, T. Exploring Student Voice in Teachers' Motivation to Use ICT in Higher Education: Qualitative Evidence from a Developing Country. Int. J. Educ. Technol. 2017, 4, 26-33. Available online: https:/ / eric.ed.gov/?id=EJ1167304 (accessed on 12 May 2021).

49. Corrales-Serrano, M.; Espejo-Antúnez, L.; Moreno-Losada, J.; Zamora-Polo, F. Motivations of the University Teacher and Performance of Transversal Competences in the Classroom. Proceedings 2018, 2, 1323. [CrossRef]

50. Kottak, C.P. Antropología Cultural; McGRAW-Hill: Madrid, Spain, 1994.

51. Cotán Fernández, A. El Sentido de la Investigación Cualitativa. Escuela Abierta 2016, 19, 33-48. Available online: http://hdl handle.net/10637/8295 (accessed on 15 May 2021). [CrossRef]

52. Angrosino, M. Etnografía y Observación Participante en Investigación Cualitativa; Ediciones Morata: Madrid, Spain, 2012.

53. Lara, G.T. La investigación cualitativa y el estudio de casos: Una revisión teórica para su discusión. Dilemas Contemp. Educ. Política Valores 2017, 4, 1-23.

54. Barquet, E.A.G.; Machado, O.J.A. El estudio de casos: Una metodología efectiva para la investigación empresarial. Rev. Espac. 2017, 38, 51 .

55. Jeong, J.S.; González-Gómez, D.; Yllana Prieto, F. Sustainable and flipped STEM education: Formative assessment online interface for observing pre-service teachers' performance and motivation. Educ. Sci. 2020, 10, 283. [CrossRef]

56. Bisquerra Alzina, R. Metodología de la Investigación Educativa; Editorial La Muralla: Madrid, Spain, 2004.

57. Martínez, A.M.; Sánchez, M.C.; Ortega, F.Z.; Zurita, M.L. La elección de estudios superiores universitarios en función de la modalidad de estudios, la nota media y el género. Magister 2015, 27, 18-25. [CrossRef]

58. Vargas, M. Entrevista Semiestructurada. Entrevista Semiestructurada: ¿Cómo Usarla en tu Investigación? Available online: https:/ / tesisymasters.mx/entrevista-semiestructurada/ (accessed on 12 May 2021).

59. Abad, P. La entrevista semi-estructurada reflexiva, una técnica cualitativa alternativa para explorar la contribución del liderazgo a los equipos de trabajo en el campo de la educación. In Memorias del Cuarto Congreso Internacional de Ciencias Pedagógicas de Ecuador: La Formación y Superación del Docente: Desafíos Para el Cambio de la Educación en el Siglo XXI; Instituto Superior Tecnológico Bolivariano: Guayaquil, Ecuador, 2018; pp. 118-126.

60. Díaz-Bravo, L.; Torruco-García, U.; Martínez-Hernández, M.; Varela-Ruiz, M. La entrevista, recurso flexible y dinámico. Investig. Educ. Médica 2013, 2, 162-167. [CrossRef]

61. Lopezosa, C. Entrevistas semiestructuradas con NVivo: Pasos para un análisis cualitativo eficaz. In Methodos Anuario de Métodos de Investigación en Comunicación Social; Lopezosa, C., Díaz-Noci, J., Codina, L., Eds.; Univ. Pompeu Fabra: Barcelona, Spain, 2020; pp. 88-97.

62. Gómez, P. La Elección del Estudio de Caso en Investigación Educativa. Gazeta Antropología 2012, 28, 14. Available online: http:/ / hdl.handle.net/10481/20644 (accessed on 16 February 2021).

63. Murillo, F.J.; Payeta, A.M.; Martín, I.M.; Lara, A.J.; Gutiérrez, R.C.; Sánchez, J.C.S.; Moreno, R.V. Estudio de Casos. Ph.D. Thesis, Universidad Autónoma de Madrid, Madrid, Spain, 2013.

64. Caïs, J. Metodología del Análisis Comparativo; Centro de Investigaciones Sociológicas: Madrid, Spain, 1997.

65. De Souza, F.N.; Costa, A.P.; Moreira, A.; de Souza, D.N.; Freitas, F. webQDA: Manual de Utilização Rápida; Universidad de Aveiro: Aveiro, Portugal, 2016.

66. Corrales, M.; Sánchez, J.; Moreno, J. The motivation in the teaching of social sciences at the hihg school. NOVA J. Educ. Rechearsh 2016, 10, 175-184.

67. Cruz Barba, E.; Silva Gutiérrez, B.N. Motivación y personalidad en la elección de carrera: Turismo y negocios internacionales. Acta Investig. Psicológica 2018, 8, 32-41. [CrossRef]

68. Ryan, R.M.; Deci, E.L. Intrinsic and extrinsic motivation from a self-determination theory perspective: Definitions, theory, practices, and future directions. Contemp. Educ. Psychol. 2020, 61, 101860. [CrossRef]

69. Hortal, A. Ética General de las Profesiones; Desclée De Brouwer: Bilbao, Spain, 2002.

70. Sánchez-Martín, J.; Zamora-Polo, F.; Alías-Gallego, D.; Moreno-Losada, J.; Espejo-Antúnez, L. ¿Ética en la educación? Instrumentos para medir, potenciar y desarrollar el razonamiento moral en ámbitos educativos multinivel. In Libro de Actas CIMIE16 de AMIE; Universidad de Sevilla: Sevilla, Spain, 2016.

71. Sánchz-García, M.F. La orientación universitaria, veinticinco años después. REOP 1999, 10, $193-206$.

72. Teppo, M.; Soobard, R.; Rannikmäe, M. A Study Comparing Intrinsic Motivation and Opinions on Learning Science (Grades 6) and Taking the International PISA Test (Grade 9). Educ. Sci. 2021, 11, 14. [CrossRef]

73. Smith, J.; Guimond, F.-A.; Bergeron, J.; St-Amand, J.; Fitzpatrick, C.; Gagnon, M. Changes in Students' Achievement Motivation in the Context of the COVID-19 Pandemic: A Function of Extraversion/Introversion? Educ. Sci. 2021, 11, 30. [CrossRef]

74. Weiss, E. Jóvenes y Bachill; ANUIES: Mexico City, Mexico, 2012; pp. 7-33. 
75. Martínez, A.M.; Sánchez, M.C.; Zurita, M.L.; Ortega, F.Z. Elección de Titulación Universitaria y Expectativas de Resultados de los Adolescentes de Granada. Rev. Española Orientación Psicopedag. 2015, 26, 63-77. Available online: https://www.redalyc.org/pdf/ 3382/338245392004.pdf (accessed on 22 January 2021). [CrossRef]

76. Martínez, A.M.; Ortega, F.Z.; Sánchez, M.C.; Cuberos, R.C.; Lucena, M.A.H.; Garcés, T.E. La elección de estudio superiores universitarios en estudiantes de último curso de bachillerato y ciclos formativos. Rev. Electrónica Educ. 2016, 20, 13. [CrossRef]

77. Cepero González, A.B. Las Preferencias Profesionales y Vocacionales del Alumnado de Secundaria y Formación Profesional Específica. Ph.D. Thesis, Universidad de Granada, Granada, Spain, 2010.

78. Martínez-Rodriguez, F.M.; Carmona-Orantes, G. Test de factores sociopersonales para la inserción laboral de los jóvenes: Un instrumento para la evaluación y la formación. Est. Educ. 2010, 18, 115-138.

79. Navarro-Guzmán, C.; Casero-Martínez, A. Análisis de las diferencias de género en la elección de estudios universitarios. Est. Educ. 2012, 22, 115-132.

80. González-Domínguez, J.; Sánchez-Barroso, G.; Zamora-Polo, F.; García-Sanz-Calcedo, J. Application of circular economy techniques for design and development of products through collaborative project-based learning for industrial engineer teaching. Sustainability 2020, 12, 4368. [CrossRef] 